\section{Hans Marius Graasvold}

Advokat

Advokatene Graasvold \& Stenvaag AS

\title{
Se meg!
}

Joharis vindu, som beskriver

de sosiale mekanismene som påvirker hvordan vi oppfattes av andre, vakte tidlig nysgjerrigheten hos meg.

Joharis vindu er en psykologisk modell utviklet for å karakterisere ulike sider ved mellommenneskelig kommunikasjon. Den ble utviklet i 1950-årene av psykologene Joseph Luft og Harrington Ingham (JoHari) og beskriver hvordan åpenhet i kommunikasjon øker når vi er tydelige og lyttende til hverandre og hvordan denne reduseres når vi ikke er det. Modellen understreker betydningen av gjensidig feedback i alt samarbeid og at evnen til å lytte er grunnleggende for å kunne danne seg et bilde av hvordan man blir oppfattet av andre.

De fleste av oss klarer å regulere hva vi deler av oss selv med omverdenen. Vi tilpasser oss omgivelsene. I mange tilfeller ønsker viat omverdenen kun ser det som i modellen kalles «Fasaden». Det ikke å dele alt med alle, er en del av det alminnelige sosiale liv.

Noen relasjoner oppstår imidlertid utenfor det alminnelige sosiale liv. Ta mitt eget fagfelt. Relasjonen mellom dommer og tiltalt er for eksempel ualminnelig og preges ofte både av manglende evne og manglende vilje til å kommunisere.

I en straffesak forsvarte jeg en utenlandsk statsborger som var tiltalt for å ha drapstruet to saksbehandlere fra kemneren som kom for å kaste ham ut av leiligheten. Sakens dokumenter levnet ingen tvil. Dette var en brutal type som verken betalte husleie eller respekterte offentlige tjenestemenn. Han møtte aldri opp til møter jeg innkalte til for å forberede saken. Kvelden før hovedforhandling rådet aktor meg i en tekstmelding å stille med skuddsikker vest under kappen. Da jeg ankom tingretten morgenen etter, møtte jeg en lutrygget, utmagret mann utenfor rettslokalet. To væpnede politimenn ransaket ryggsekken hans. Dommeren ga oss ti minutter på gangen tilå snakke sammen før saken begynte.

Jeg forsto hvorfor mannen hadde et noe anstrengt forhold til myndighetspersoner. Etter ni måneder med tortur i et utenlandsk forhørsfengsel flyktet han til Norge, der han fikk asyl. Han var nå alvorlig kreftsyk og sterkt medisinert. Avkreftet og arbeidsufør hadde han tilbrakt det siste halve året innendørs og holdt varmen ved hjelp av telys etter at strømmen ble stengt. En januarmorgen ringte saksbehandlerne på og beordret ham til å forlate leiligheten umiddelbart. Da han ble nektet tid til å kle seg. raknet det for ham. Han fremkalte, som det sto i tiltalebeslutningen, ved bruk av trusler frykt for liv og helse. Til hans store lettelse viste dommeren interesse for hvem som egentlig sto på tiltalebenken. Mannen slapp å sone og fikk en ny mulighet i livet.

Overført til skolemedisinen kan man si at straffebestemmelser er jusens måte å diagnostisere en uønsket handling. Straffeutmålingen (kriminalomsorgen) er behandlingen. For å stille riktig diagnose og gi god behandling er særlig kriminologene opptatt avå se mennesket bak handlingen og forstå vedkommende ut fra hennes eller hans virkelighet. Ofte er denne preget av fravær av normalitet og forutsigbarhet.

Min mor har gjennom årene tegnet et liknende bilde fra sitt fagområde. Hun har i 30 år arbeidet med barn og unge med spiseforstyrrelser. Fellesnevneren for disse er at sykdommen har kastet dem ut av normaltilværelsen til en permanent unntakstilstand. Som på mitt fagområde må forståelsen av personens handlinger og atferdsmønster baseres på hva man finner bak fasaden. For å oppnå dette må man forsøkeå forstå pasienten og få vedkommende til å forstå hvordan man - fagpersonen ser han eller henne.

I behandlingen av disse barna er frafall fra behandlingen og tilbakefall et stort problem. Parallellen til strafferetten er slående. På begge områder er utfordringen å vinne tillit hos den det gjelder og få vedkommende til å bryte ut av negative handlingsmønstre.

Noen ganger er diagnosen riktig, men evnen til behandling fraværende. I Aftenposten i vinter kunne vi lese om en ung. anoreksisyk jentes opplevelse av å være kasteball mellom ulike avdelinger og institusjoner. Akuttmedisinsk avdeling ville ikke ha henne, for anoreksi er en psykisk lidelse. Psykiatrisk avdeling mente hun måtte inn på medisinsk. Regional avdeling for spiseforstyrrelser har ventelister på 8-12 måneder. Jenta beskrev et apparat som manglet blikket for henne som menneske.

Som advokat føler jeg ofte at jeg gjør mitt beste når jeg agerer mer som menneske og mindre som advokat. Jeg tror man som helsepersonell har mye å hente på å tørre det samme. Sett gjennom Joharis vindu kan det hende både du og andre fremstår i nytt lys.

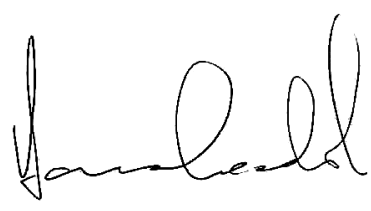

